\title{
INVISIBLE TECHNOLOGIES, INVISIBLE BOUNDARIES?
}

Dealing with Household technologies.

\author{
Katja Oksanen-Särelä \\ Future Media Home, Media Lab Helsinki University of Art and Design,Helsinki, Finland.
}

Key words: Smart home, habit, agency, invisibility.

\begin{abstract}
This article discusses technology in everyday life, especially in the context of smart home, as described in future documents. It is claimed that as the autonomous nature of the user is emphasised, the everyday, routine aspects of technology use are ignored. Also other possible limitations to users agency which are more technological by nature are discussed. It is claimed that more invisible the technologies become, more important it is to make visible the underlying conditions of technologies.
\end{abstract}

\section{INTRODUCTION}

Individuals are more and more exposed to new technologies as part of their daily lives and this tendency seems to be strengthening in the future. All kinds of new technologies, especially information technologies, have been introduced in the home during recent years. The domestication of these technologies has been dependent on how the need for them is created and on how they have been able to utilize existing social and technological spaces. This utilization of space is technological in the way technology incorporates into the existing space of technological infrastructure, and social in a way technologies incorporate into existing patterns of use and habits. As new technologies emerge, they also start incorporating into spaces where they haven't existed. Social space is constantly recreated as people incorporate technologies into their daily lives and routines.

I have studied how the relationship between individual and technology in everyday life is described in future documents (see [9]). The way I approach 
future visions could be called as a variant of constructivism. Scenarios don't just describe but also create social reality and its that way they work as selfrealizing prophesies. [1]. With this idea in mind I aim to examine some of the representations that have been made of the user relationship with technology, technologies at home in particular.

\section{TECHNOLOGIES AT HOME}

First let us look at how the technology use in everyday life may be conceptualised. Venkatesh [10] has represented the internal structure of the household-technology interaction as follows, the different areas of life and social actions (social space) have an equivalent on the technologies used (technological space). I have added emerging technologies to the table which are, according to future visions, changing the existing patterns of behavioural and technological usage. (Table 1). Old technologies have an important role as they are creating the technological space for doing things and preparing the space way more complex technologies to come.

Our lives are mediated in a new way by an assemblage of technologies that connect and overlap. On the ground of visions the technological space is encroaching on social space as more and more everyday activities are carried through technological mediator. Tele-everything (shopping, banking, working, health services, socialising) is a good example of this as virtuality enables different actions, which are not dependent on time or place.

People have for a long time developed machines and technologies to help them in different areas of life through controlling time and physical environment. Warde et al [11] have made a distinction between modern and hypermodern devices. Modern technologies and devices (modern "conveniences") have been effected towards saving time and labour, the fastness been seen as a most important factor. In recent times the need for more profound manipulation of time and place has been articulated [6]. This kind of technology, which may be called hypermodern, allows flexibility in a matter of when and where to perform certain tasks. It also allows one to do different things simultaneously. Different machines which work with a timer like a video recorder are a good example of this since they do not necessarily make things faster but with them it is possible to arrange and plan ones personal use of time. They don't require the user to be present all the time but they can do things independently [11]. As technologies make possible overcoming the limitations of time and place they have fostered the idea of freedom and individuality. With technologies the person has been able to take control of his life surroundings, whether it is to free himself from the 
restraints of space (a car) or time (technologies that can be used on users own schedule) [5], [7].

Table 1. Sub-environments at home

\begin{tabular}{|c|c|c|c|}
\hline Area & $\begin{array}{l}\text { Household } \\
\text { activities targeted } \\
\text { for technology use }\end{array}$ & $\begin{array}{l}\text { Configuration of } \\
\text { household } \\
\text { technologies }\end{array}$ & $\begin{array}{l}\text { Emerging } \\
\text { technologies }\end{array}$ \\
\hline Food management & $\begin{array}{l}\text { meal preparation and } \\
\text { consumption. } \\
\text { washing dishes etc, } \\
\text { grocery, shopping }\end{array}$ & $\begin{array}{l}\text { appliances, } \\
\text { automobile, } \\
\text { computer, } \\
\text { home shopping }\end{array}$ & $\begin{array}{l}\text { auto-cook, automated } \\
\text { cleaning facilities, } \\
\text { home shopping }\end{array}$ \\
\hline $\begin{array}{l}\text { Household } \\
\text { maintenance/ } \\
\text { finance }\end{array}$ & $\begin{array}{l}\text { family shopping, tax } \\
\text { preparation etc }\end{array}$ & $\begin{array}{l}\text { dryer, automobile, } \\
\text { on-line home } \\
\text { banking }\end{array}$ & $\begin{array}{l}\text { on-line home } \\
\text { banking, } \\
\text { e-commerce }\end{array}$ \\
\hline $\begin{array}{l}\text { Leisure/ } \\
\text { Recreation/ } \\
\text { Entertainment }\end{array}$ & $\begin{array}{l}\text { watching TV, } \\
\text { holiday travel, } \\
\text { movies, games }\end{array}$ & $\begin{array}{l}\text { stereo, automobile, } \\
\text { computer, } \\
\text { multimedia }\end{array}$ & $\begin{array}{l}\text { virtual environments } \\
\text { controlling and } \\
\text { producing media } \\
\text { content }\end{array}$ \\
\hline $\begin{array}{l}\text { Social/ } \\
\text { Family } \\
\text { Communication }\end{array}$ & $\begin{array}{l}\text { telephone, } \\
\text { conversations, } \\
\text { family } \\
\text { communication }\end{array}$ & $\begin{array}{l}\text { answering machine, } \\
\text { fax, automobile, } \\
\text { computer, internet }\end{array}$ & $\begin{array}{l}\text { connected } \\
\text { communications } \\
\text { systems }\end{array}$ \\
\hline $\begin{array}{l}\text { Work/ } \\
\text { Employment }\end{array}$ & $\begin{array}{l}\text { job-related activities, } \\
\text { commuting to work }\end{array}$ & $\begin{array}{l}\text { answering machine, } \\
\text { fax, automobile, } \\
\text { computer, internet }\end{array}$ & $\begin{array}{l}\text { mobile office: } \\
\text { portable equipment } \\
\text { with instant } \\
\text { connections } \\
\text { (everything in one } \\
\text { device.) }\end{array}$ \\
\hline $\begin{array}{l}\text { Family/ } \\
\text { Development/ } \\
\text { Well-being }\end{array}$ & $\begin{array}{l}\text { education, gathering, } \\
\text { dieting }\end{array}$ & $\begin{array}{l}\text { VCR, telephone, } \\
\text { computer, internet }\end{array}$ & $\begin{array}{l}\text { virtual learning and } \\
\text { gathering } \\
\text { environments, } \\
\text { devices for observing } \\
\text { one's health }\end{array}$ \\
\hline
\end{tabular}

In the new technologies this idea of taking control can be seen for example in a discussion about their interactive properties. The users of older media such as TV are "consumers" and passive recipients. In new technology, however, users are actors and active creators of content (see, for example, [7]). In the interactive visions, viewing and enjoying has been replaced by creating and managing. It is seen that as a consumer becomes a user, she/he gains more individual agency and autonomy. Still, there are some restrictions in this agency, which I will turn to in section 3. 


\section{LIMITATIONS OF AGENCY}

In the future visions the user is active and knowledgeable in using technologies. The relationship with technology is presented as unproblematic; the user has taken over the appliance, controlling it. This view of active use can be questioned, though, if we think about how we act in daily life. Not everything we do is fully intentional or even conscious. There are many kinds of daily acts in which we engage ourselves, without effort or reflection. Those are kind of acts which are are small, repeated and taken-for-granted. Furthermore, every rationally calculated and willed action may, over time, become an unconsidered, automatic, habitual routine [3] as habits become internalized.

Habits are kinds of cognitive and bodily molarities of actions, which are interconnected. When using technologies, we grasp them as molarities in a way that our image of the technology contains the technological devices but also practices that are attached to them. For instance, starting the PC consists on several connected actions, which we don't usually pay attention to. Thus, habits may be defined as learned, yet un-thought techniques of the body. As the new technologies come a part of our functioning in everyday life they disappear from active view; from conscious memory to bodily memory [12]

Habits as themselves may be personal by nature but the way single acts grow into habits is not dependent on individual will or desire. The configuration of the social space is embodied in our habits (Wise 1997, 76) This social space gives some space to individual styles of doing things but it also defines the limits of action. We may think about Lefebvres illustration of negotiating social space as though walking through the city. First we have the practice of walking the city. Secondly, we have an abstract map, a conceptualisation of the space, which guides our interpretation of the city, our possibilities of moving around etc. Third, the city has been built in a certain way, which is independent of an individual, and the walk actualizes these possibilities and obstacles it sets. One may move around in the city in stylistically resistant ways but there is little one can do to stop or reroute traffic - to reconfigure the space [12]

There are hidden structures, "internal scripts", of technologies, which guide how the user acts with a given technology. When we use artefacts we automatically put into practice these ideas of this script [8], [4]. One might say that through routinized practices we internalize the requirements of the technological system. For example, we use the pc independently and we seem to be in control of our own work rhythm. Still, in the pc and its software there are properties which imply a certain kind of user - a fast, effective user, for example. The properties are built on the work processes 
which the user automatically puts into practice. There are cases in different products where the uses of products might be different than the producers and designers have thought. Still, this doesn't really apply to complex technologies. More complicated the technology, less it gives space to different ways of using it as the user doesn't have the skills or knowledge on affecting its functioning.

This can be understood when we think about the issue of smart home. In smart home everything is highly automated. There are control technologies for children and elderly and different self-monitoring devices that operate relatively independently. The energy consumption and air conditioning in the building as well as the influx of information and entertainment are automated. Smart cards, entrance surveillance systems and television cameras create a feeling of security. Technology is taking care of everyday household chores with autochef and cleaning facilities. What is essential is that all technical functions are integrated, in a way that the inhabitant doesn't have any immediate means of effecting these environments, and complex so that the inhabitant can't have control over the system itself. What when there are technical problems, total disorder in the smart home? Are we to expect that the smart system could be switched off if we so wished?

In the idea of new technologies there is an assumption of strong agency of the user. With increasing interactiveness of smart systems the question of agency is not so straightforward, though. Note the term "intelligent agent" which is commonly used. With smart systems although we speak of "machines that learn and are customised to the user's preferences", we may be dealing with a completely new level of dependency. Take, for example, a personal robot connected to digital TV, which seeks the channels for the viewer's favourite programs based on preferences revealed by previous watching choices. At the same time, the program robot of the media operator continuously monitors the changing of TV channels in households. The program robot learns "from experience" at what dramaturgical points people stop watching a program. Finally the robot learns to select the programs from the producers' list that will attract a maximum audience. The programcompiling robot in the media production unit then receives this information and begins to prepare combinations of different series of programs offering maximal satisfaction - as well as maximum dependency - to the viewer.

\section{INVISIBLE TECHNOLOGIES}

If compactness and lightness were important features in the (hyper)modern technology, the new technology is everywhere around us. We 
don't have to carry any gadgets with us but the technology is either with us, maybe built-in in our bodies, or in the surroundings ("smart objects"). Technology is coming to physical places and objects where it has been absent so far. It is also spreading to novel social spaces as the scope of activities and life areas where technologies are as mediator broadens. Still, at the same time technology becomes ever more pervasive, it becomes ever more invisible around us.

Besides the auto-cook and automated cleaning gadgets, home will offer a host of sensors and controls for lights, temperature, doors latches, burglars and fire and gas alarms, entertainment, health monitoring, babysitting, and package reception systems, live or changeable visual displays; multiple communications pipes to cable, telephone, wireless and satellite links; and out door amenities like pool water purification and garden irrigation. Once the electronics are integrated into the house and with one another, you will not notice them any more or less than you notice your present hot water heater, furnace, refrigerator, washer and dryer and other electromechanical gadgets. The difference, of course, is that the new devices will communicate with one another about their goals and their problems. (Dertouzos [3]).

This kind of new technology doesn't scream for our attention, but it is discreetly in the background. This is interesting in the light of habit since more inconspicuous the technologies are, more difficult it is to define their affects on our daily conduct. As Mark Weiser has written: "The most profound technologies are those that disappear. They weave themselves into the fabric of everyday life until they are indistinguishable from it. "

\section{REFERENCES}

[1] Bijker W. E. and Pinch T. (1987)"The Social Construction of Facts and Artefacts". In Bijker W.E., Hughes T and Pinch T (Eds.) "The Social Construction of Technological Systems: New directions in the sociology and history of technology". 17-50. MIT Press, Cambridge, Mass.

[2] Campbell C. (1996) "Detraditionalization, Character and the Limits of Agency". In Heelas P, Lash S and Morris P (Eds.) "Detraditionalization. Critical Reflections on Authority and Identity". 149-169. Blackwell, Cambridge, MA.

[3] Dertouzos M. (1997) "What will be. How the new world of information will change our lives". Harper Edge, New York.

[4] Edwards P. N. (1995) "From Impact to Social Process. Computers in Society and Culture". In Jasanoff S, Markle G.E, Petersen J.C and Pinch T (Eds.) "Handbook of Science and Technology Studies".257-285. Sage, Thousand Oaks.

[5] de Grazia S. (1994) "Of Time, Work and Leisure". Vintage Books, New York.

[6] Kaufman C. F. and Lane P. M. (1996) "Time and Technology. The Growing Nexus". In Dholakia R.R, Mundorf R and Dholakia N (Eds.) "New Infortainment Technologies in the Home" .135-154. Lawrence Erlbaum Associates. Mahwah, New Jersey. 
[7] de Kerchove D. (1997) " The Skin of Culture. Investigating the New Electronic Reality". (Dewdney C, Ed.). Kogan Page, London.

[8] Markussen R. (1995) "Constructing Easiness - historical perspectives on work, computerization and women". In Leigh Star S (ed.) "The Cultures of Computing"158181. Blackwell Publishers, Oxford.

[9] Oksanen-Särelä K. - Pantzar M. (2000) "Smart Life Version 3.0 Representations of everyday life in future studies". In Gronow $\mathrm{J}$ and Warde A (Eds.): "Ordinary Consumption". Harwood, forthcoming.

[10] Venkatesh A. (1996) "Computers and Interactive Technologies for the Home. The use and impact: past, present and the future". Communications of the ACM, December.

[11] Warde A, Shove E. and Southerton D (1998) "Convenience, schedules and sustainability". Draft paper for ESF Workshop on sustainable consumption, Lancaster, March 27-29, 1998.

[12] Wise J. M. (1997) "Exploring technology and social space". Sage, London. 